\title{
(อ) \\ OPEN ACCESS \\ Methodological issue on prediction of emergency cesarean section by measurable maternal and fetal characteristics
}

\author{
Masoumeh Abbasi, ${ }^{1}$ Mehdi Naderi [i] ${ }^{2}$
}

${ }^{1}$ Department of Health Information Technology, Kermanshah University of Medical Sciences, Kermanshah, Kermanshah, Iran (the Islamic Republic of) ${ }^{2}$ Clinical Research Development Centre, Taleghani and Imam Ali Hospital, Kermanshah University of Medical Sciences, Kermanshah, Iran (the Islamic Republic of)

\section{Correspondence to} Dr Mehdi Naderi, Clinical Research Development Centre, Taleghani and Imam Ali Hospital, Kermanshah University of Medical Sciences, Kermanshah, Iran (the Islamic Republic of); m.naderi51@yahoo.com

Accepted 23 April 2020 Published Online First 4 June 2020

\section{SLinked}

- http://dx.doi.org/10.

1136/jim-2019-001175

- http://dx.doi.org/10.

1136/jim-2020-001404

Check for updates

(C) American Federation for Medical Research 2020.

Re-use permitted under CC BY-NC. No commercial re-use. Published by BMJ.

To cite: Abbasi M, Naderi M. J Investig Med 2020;68:1024.
Dear Editor,

We read with great interest the study by Ping Guan et al. The authors aimed to develop a simple and distinctive scoring system for predicting the risk of emergency cesarean section (EmCS) during vaginal delivery. ${ }^{1}$ In their study, data of 10295 women were studied retrospectively; 9304 of cases had vaginal delivery and 991 cases had EmCS during the process of vaginal delivery. Univariate analysis was applied to consider the relationship between the EmCS rate and perinatal factors. Also, multiple logistic regression analysis was applied to find factors independently associated with the risk for EmCS. The area under the curve (AUC) was used to show predictive ability of the risk scoring system. Nine maternal and infant factors were used to develop the risk scoring system as independent risk factors of EmCS. The results showed the AUC for risk scoring was 0.787 (95\% CI 0.772 to 0.801$){ }^{1}$

Despite these interesting results, there are some methodological issues that we will mention below. To develop a prediction model, a cohort study is required in which data can be divided into two groups: failure and success. The next point is to examine the validity of the prediction model, which includes both internal and external validity; if they are not reviewed, bias may interfere with its generalizability to similar populations. Generally, when prediction models are without validation, spurious results can be observed in the outcome. There are different methods for validation of a prediction modelfor example, the split file, bootstrapping or other well-known validation methods. ${ }^{2-4}$ Without paying attention to the modeling technique, if the dataset is small (which was not the case here) with many candidate predictors, and when the predictor selection techniques have been used, the bootstrapping method is particularly recommended. ${ }^{5}$ Finally, the AUC is used to survey the model's accuracy, not for predictive ability, and its statistical significance does not guarantee any prediction. Determining of the optimal cutting point based only on the data of the developing model is wrong, which this action often causes misleading predictors, over fitting, reducing reliability and applicability of model predictions in new patients. ${ }^{67}$ Another important point that needs to be addressed in this study is the effect of interactions among variables that failure to investigate can lead to misleading results. ${ }^{24}$

The authors conclude that the risk scoring system simply and easily assesses the risk of EmCS based on measurable maternal and fetal characteristics. ${ }^{1}$ In this letter, we have discussed how to properly evaluate the prediction of outcome or develop the score. Any conclusions about these fields should be supported by the above mentioned methodology issues. Otherwise, misinterpretation cannot be avoided.

Contributors MA and MN: conceived, designed, manuscript writing.

Funding The authors have not declared a specific grant for this research from any funding agency in the public, commercial or not-for-profit sectors.

Competing interests None declared.

Patient consent for publication Not required.

Provenance and peer review Not commissioned; internally peer reviewed.

Open access This is an open access article distributed in accordance with the Creative Commons Attribution Non Commercial (CC BY-NC 4.0) license, which permits others to distribute, remix, adapt, build upon this work non-commercially, and license their derivative works on different terms, provided the original work is properly cited, an indication of whether changes were made, and the use is non-commercial. See: http://creativecommons.org/licenses/ by-nc/4.01

ORCID iD

Mehdi Naderi http://orcid.org/0000-0002-5608-6582

\section{REFERENCES}

1 Guan P, Tang F, Sun G, et al. Prediction of emergency cesarean section by measurable maternal and fetal characteristics. J Investig Med 2020;68:799-806.

2 Abbasi M, Naderi M. What does need to know about developing clinical prediction models? J Geriatr Oncol 2019;10:369

3 Grobbee DE, Hoes AW. Clinical epidemiology: principles, methods, and applications for clinical research. Jones \& Bartlett Learning, 2009.

4 Szklo M, Nieto FJ. Epidemiology beyond the basics. 3rd edn. Manhattan, New York: Jones and Bartlett Publisher, 2014.

5 Altman DG, Royston P. What do we mean by validating a prognostic model? Stat Med 2000;19:453-73.

6 Royston P, Altman DG, Sauerbrei W. Dichotomizing continuous predictors in multiple regression: a bad idea. Stat Med 2006:25:127-41.

7 Altman DG, Royston P. The cost of dichotomising continuous variables. BMJ 2006:332:1080. 